\title{
Production and Economic Effects of Environmentally Friendly Spring Wheat Production Technology
}

\author{
Małgorzata Haliniarz ${ }^{1}$, Anna Nowak ${ }^{2 *}$, Andrzej Woźniak ${ }^{1}$, \\ Tomasz R. Sekutowski ${ }^{3}$, Cezary A. Kwiatkowski ${ }^{1}$ \\ ${ }^{1}$ Department of Weed Science and Plant Cultivation, University of Life Sciences in Lublin, Lublin, Poland \\ ${ }^{2}$ Department of Economics and Agribusiness, University of Life Sciences in Lublin, Lublin, Poland \\ ${ }^{3}$ Department of Weed Science and Tillage Systems, Wrocław, Poland; Institute of Soil Science and Plant Cultivation, \\ National Research Institute, Puławy, Poland
}

Received: 21 July 2017

Accepted: 18 September 2017

\begin{abstract}
The aim of the present study was to evaluate yield, grain quality characteristics, and cost-effectiveness of different crop protection methods in the cultivation of spring wheat using two levels of mineral fertilization of crops. The study shows that the combined application of the herbicide Lintur $70 \mathrm{WG}$ (dicamba and triasulfuron) with ethephon or chlormequat chloride did not adversely affect spring wheat productivity. The highest yield was obtained in the treatment with intensive fertilization $\left(5.18 \mathrm{t} \mathrm{ha}^{-1}\right)$ and in the treatments with the application of herbicide in combination with ethephon $\left(5.26 \mathrm{t} \mathrm{ha}^{-1}\right)$. The chemical crop protection methods caused significant differences in grain test weight. In turn, mineral fertilization modified all the studied grain quality characteristics. An analysis of the indicators used to evaluate the economic effects of the spring wheat production technologies investigated showed a clear advantage of the lower intensity technology over the more intensive technologies, which should be associated with the high costs of mineral fertilization that were not compensated by the yields obtained. In analyzing the production and economic effects, treatment with the application of the herbicide in combination with ethephon under basic mineral fertilization conditions proved to be most beneficial.
\end{abstract}

Keywords: cultivation technology, economic results, grain quality, Triticum aestivum, yield

\section{Introduction}

The cereals market belongs to the most important agricultural produce markets in Poland. During 20102013 the value of total cereal production ranged from

*e-mail: anna.nowak@up.lublin.pl
$€ 62,139.0$ million in 2010 to $€ 84,866.5$ million in 2013 . The share of cereals in total agricultural production over the period in question showed an increasing trend until 2012 , when it stood at $22.2 \%$, whereas in 2013 it declined to $19.1 \%$. As regards the crop structure, during 2010-2013 cereals accounted on average for $73.6 \%$ of Poland's total crop area. The popularity of growing cereals results from the favorable climatic and soil conditions prevailing in 
Poland, the relatively simple production technology of cereals, and relatively low labor intensity, as well as easy storage, transport, and sale [1-2]. In turn, the economic importance of cereals arises from their role in the food industry and thus in ensuring national food security. Cereals are therefore treated as agricultural raw materials of strategic importance. Moreover, their large production potential provides the possibility of competing in the cereals market with other countries.

Wheat plays a special role here; its average share in the value of Poland's total agricultural production over the period $2010-2013$ was $7.5 \%$, while its value of agricultural commodity production was $7.3 \%$. Wheat is a strategic cereal for most of the world's population. It is one of eight major sources of food (wheat, rice, maize, sugar, cattle, sorghum, proso millet, and cassava) that together account for $70-90 \%$ of all calories and $66-90 \%$ of protein consumed in developing countries [3-4]. Crop fertilization level is one of the main factors determining crop yields. However, intensive nitrogen fertilization increases the crop's susceptibility to lodging, which can be a reason for significant crop losses. High plants with poorly developed mechanical tissue exhibit much greater susceptibility to lodging. To strengthen plants, the so-called retardants, i.e., growth regulators, are used. Apart from shortening plants, retardants increase the photosynthetic rate and productivity, stimulate root growth, and beneficially affect nutrient absorption and assimilate transport in the plant [5-8].

Production technologies are derivatives and elements of farming systems used in agricultural practice. The value of individual farming systems is determined by economic evaluation, alongside production and ecological indicators [9]. Inputs associated with technology intensity are an extremely important element that determines the profitability of crop production [10-11]. In a market economy, decisions related to the selection of technology used or its intensity level are made primarily based on the evaluation of inputs and outputs achieved. The volatility of the environment in which agricultural producers operate determines the need to review systematically the profitability of individual production activities and the production technologies used. Under market economy conditions, cost-effectiveness is a major criterion in production management, while the effective use of production factors is an issue that determines the competitiveness of a farm as a whole [12].

Cost-effectiveness is expressed as the ratio of inputs to outputs produced using such inputs. Production costs and gross margin are often used to compare agricultural holdings, products, or technologies in order to show competitive advantages [13]. A comparison of outputs and inputs allows us to make a technical evaluation of the efficiency of the production technology used and the effectiveness of farm management [14]. Moreover, the quality characteristics of products produced are an important criterion in making decisions on the selection of production technology, because quality is one of the more important sources of market competition. This problem is undertaken by many scientists who focus their attention on the aspects associated with both ensuring an adequate level of production efficiency and obtaining appropriate quality parameters [15-16]. The studies of many authors demonstrate that producers cannot always directly influence the quality of products produced. Among the factors that are dependent on farmers, the following are mentioned: nitrogen fertilization level and timing; protection against weeds, diseases, and pests; and storage method and time [17-20]. On the other hand, factors independent of agricultural producers include primarily weather conditions [19, 21].

Our research hypothesis was that the application of retardants would contribute to higher crop yields and improved grain technological quality, in particular under intensive nitrogen fertilization conditions. The study also hypothesized that the combined application of growth regulators (retardants) and herbicides would produce the same yield-increasing effect as the application of these chemicals separately, in accordance with the manufacturer's recommendations, and at the same time it would reduce inputs used in the production of spring wheat grain.

The aim of the present study was to evaluate yield, grain quality characteristics, and cost-effectiveness of different crop protection methods in the cultivation of spring wheat using two levels of mineral fertilization.

\section{Materials and Methods}

\section{Description of the Experiment}

The study was conducted in 2010-2013 at the Czesławice Experimental Farm ( $\left.51^{\circ} 18^{\prime} 23^{\prime \prime} \mathrm{N}, 22^{\circ} 16^{\prime} 2^{\prime \prime} \mathrm{E}\right)$. The experiment was located on grey-brown podzolic soil derived from loess with the grain-size distribution of silt loam, classified as good wheat soil complex. The arable layer was characterized by slightly acidic $\mathrm{pH}$ (5.9-6.21 in $1 \mathrm{M} \mathrm{KCl}$ ), a humus content of $1.48 \%$, very high availability of phosphorus $(29.2 \mathrm{mg}$ per $100 \mathrm{~g}$ of soil) and potassium (23.7 $\mathrm{mg}$ per $100 \mathrm{~g}$ of soil), and high availability of magnesium (8.5 mg per $100 \mathrm{~g}$ of soil). The experiment was set up as a split-plot design in four replicates, in plots with a sown area of $2.7 \times 10.0 \mathrm{~m}$ and a harvested area of $1.5 \times 10.0 \mathrm{~m}$. The spring wheat cultivar 'Korynta' was the object of the study. The experimental design included two factors. The following chemical control treatments were the first experimental factor:

A - the herbicide Lintur 70 WG (dicamba+triasulfuron) applied at growth stage BBCH 21-22

$\mathrm{B}$ - the herbicide Lintur $70 \mathrm{WG}$ (dicamba+triasulfuron) applied at BBCH 21-22 and the growth retardant Antywylegacz Płynny 675 SL (chlormequat chloride) applied at BBCH 31-32

$\mathrm{C}$ - the herbicide Lintur 70 WG (dicamba+triasulfuron) applied in combination with the growth retardant Antywylegacz Płynny 675 SL at BBCH 30

$\mathrm{D}$ - the herbicide Lintur $70 \mathrm{WG}$ (dicamba+triasulfuron) 
applied at $\mathrm{BBCH}$ 21-22 and the growth retardant Cerone 480 SL (ethephon) applied at BBCH 31-32

$\mathrm{E}$ - the herbicide Lintur 70 WG (dicamba+triasulfuron) applied in combination with the growth retardant Cerone 480 SL (ethephon) at BBCH 30

Lintur $70 \mathrm{WG}$ was applied at a rate of $0.15 \mathrm{~kg} \mathrm{ha}^{-1}$, Antywylegacz Płynny $675 \mathrm{SL}$ at a rate of $1.5 \mathrm{~L} \mathrm{ha}^{-1}$, and Cerone $480 \mathrm{SL}$ at $0.75 \mathrm{~L} \mathrm{ha}^{-1}$. The other experimental factor consisted of two levels of mineral fertilization: basic fertilization (F1) N-60, P-22, K-50 kg ha-1 (176 kg ha-1 of ammonium nitrate, $109 \mathrm{~kg} \mathrm{ha}^{-1}$ of triple superphosphate, $100 \mathrm{~kg} \mathrm{ha}^{-1}$ of potassium salt); and intensive fertilization (F2) N-120, P-42, K-100 kg ha-1 (353 kg ha-1 of ammonium nitrate, $206 \mathrm{~kg} \mathrm{ha}^{-1}$ of triple superphosphate, $200 \mathrm{~kg} \mathrm{ha}^{-1}$ of potassium salt). All phosphorus and potassium fertilizers were applied 2-3 days before sowing the crop. In the treatments with the basic rate of NPK, nitrogen was applied before sowing, whereas in the plots with the higher NPK rate $25 \mathrm{~kg} \mathrm{~N}$ was additionally supplied at stem elongation.

Tillage operations were carried out before sowing in accordance with the recommendations. In the spring, harrowing was performed, then the soil was tilled using a tillage implement consisting of a cultivator and a cage roller, and subsequently mineral fertilization was applied ( $\mathrm{P}, \mathrm{K}$ fertilizers and partially $\mathrm{N}$ fertilizer). The fertilizers were mixed with the soil using a mid harrow. Before sowing, seeds were dressed with the seed dressing Raxil Gel 206 (thiuram + tebuconazole) at a rate of $500 \mathrm{ml}$ per $100 \mathrm{~kg}$ of seed. Chemical control of fungal diseases and pests was done according to the recommendations of the Institute of Plant Protection in Poznań and it involved the application of the fungicides Tilt Plus $400 \mathrm{SC}$ (propiconazole + fenpropidin) at $1.0 \mathrm{~L} \mathrm{ha}^{-1}$ and Amistar $250 \mathrm{SC}$ (azoxystrobin) at $1.0 \mathrm{~L} \mathrm{ha}^{-1}$, as well as the insecticide Fastac 100 EC (alpha-cypermethrin) at $0.12 \mathrm{~L}$ $\mathrm{ha}^{-1}$. Wheat was sown in the first 10 days of April at an amount of 4.5 million seeds per hectare.

\section{Yield Components}

Plant height of spring wheat was determined based on the measurement of 30 plants, randomly selected from each plot. The analysis of the ear structure was performed based on 30 ears randomly selected from the plot. 1,000-grain weight for each plot was determined in two replicates with 500 grains in each. Ear density was calculated in a $0.5 \mathrm{~m}^{2}$ area in two randomly selected places of the plot.

\section{Chemical and Physical Analyses}

The contents of protein, gluten, and starch as well as the Zeleny sedimentation value were determined on an Omega Analyzer $G$ spectrophotometer at the Department of Agricultural Ecology of the University of Life Sciences in Lublin. Grain test weight was determined on a 1.0 liter grain test weight scale, while grain uniformity was evaluated using grain screens.

\section{Statistical Analyses}

The obtained results were statistically analyzed using analysis of variance. The significances of difference were estimated using Tukey's test at a significance level of 0.05 .

\section{Economic Analysis}

To make an economic evaluation of the spring wheat production technologies studied, the following economic categories used in the Farm Accountancy Data Network were employed: gross margin and operating income. According to the EU methodology, the gross operating margin (in this case the margin earned on the cultivation of spring wheat) is the annual output per hectare of crop less the direct costs incurred to produce this output [22]. Direct costs reflect costs incurred throughout the entire production cycle, and in accordance with the EU guidelines they should meet the following three conditions:

- They can be attributed without any doubt to a specific activity

- Their amount has a proportional relationship with the scale of production

- They directly impact the size (volume and value) of the output.

In turn, operating income is the excess left after total cost items (direct and indirect costs) have been deducted from the value of the output. Two income categories were calculated in this study: operating income without direct payments and operating income with direct payments. In relation to the former, the latter income was increased by adding production-related direct payments, i.e., a supplementary payment as well as the refund of excise tax on diesel fuel used for agricultural production. Furthermore, to evaluate the production and economic effects as well as the cost-effectiveness of inputs, we used the unit cost of production, the profitability ratio, and a set of economic efficiency measures according to the methodology of the Institute of Agricultural and Food Economics (IERiGŻ) in Warsaw.

\section{Results and Discussion}

\section{Spring Wheat Productivity}

Crop yield is the main determinant that proves the correctness of the selection of a specific production technology. In the present experiment, spring wheat grain yield was significantly modified by both the crop protection method and mineral fertilization level. The results of other authors' studies concerning the effect of retardants on the productivity of cereals vary substantially. Some of them showed retardants to have a positive effect on the yields obtained [5, 23], while others did not find retardants affecting crop productivity $[7,24]$. The results obtained in the present study, except for the separate application of the growth retardant Antywylegacz Płynny 675 SL and 
the herbicide (B), showed the retardants to have a positive effect on spring wheat yield. The combined application of the herbicide and retardants also beneficially affected grain yield. The mixture with the retardant, both with Antywylegacz Płynny 675 SL and Cerone 480 SL, was found to positively influence wheat productivity, but in treatment $\mathrm{E}$, in which the herbicide Lintur $70 \mathrm{WG}$ and the retardant Cerone 480 SL were applied in combination, a significant increase in yield was found (by $6.4 \%$ ) relative to the control treatment (A). Miziniak and Praczyk [25] did not find the combined application of fenoxaprop-P-ethyl with chlormequat chloride and prohexadione calcium to adversely influence winter wheat yield, whereas in another study Miziniak and Praczyk [26] proved that the grain yield harvested from the plots treated with mixtures of sulfosulfuron and retardants was higher compared to the yield harvested from the treatments with the separate application of the above-mentioned chemicals. Most studies show mineral fertilization to have a positive effect on wheat productivity, with this effect being greatest in the case of nitrogen fertilization [21, 27-28]. Nevertheless, not all studies confirm this tendency. Silva et al. [7] did not prove that different $\mathrm{N}$ rates affect wheat yield. Duan et al. [29] proved that the grain yield of winter wheat under $150 \mathrm{~kg} \mathrm{~N}$ ha $^{-1}$ increased from 51.4 to $66.6 \%$ compared with controls. In the present experiment, intensive mineral fertilization, including the increase in the fertilizer rate by $100 \%$, resulted in an increase in grain yield on average by $0.31 \mathrm{t} \mathrm{ha}^{-1}$, i.e., by $6.4 \%$. This relatively small increase in grain yield, despite the fact that in this experiment it was significantly higher, is due to the high natural fertility of soils in wheat soil complexes, which reduces the effectiveness of high nitrogen rates. This is confirmed by the study of Harasim et al. [21] conducted on soils of good wheat soil complex; these authors did not show that increasing the nitrogen rate from 100 to $150 \mathrm{~kg} \mathrm{ha}^{-1}$ resulted in an increase in winter wheat yield.

The experimental factors evaluated also caused differences in 1,000 grain weight (TGW) of spring

Table 1. Yield and yield components of spring wheat depending on the crop protection method and mineral fertilization level (mean from 2010-2013).

\begin{tabular}{|c|c|c|c|c|c|c|c|}
\hline \multirow{2}{*}{$\begin{array}{l}\text { Fertilization } \\
\text { (F) }\end{array}$} & \multirow{2}{*}{$\begin{array}{l}\text { Chemical } \\
\text { protection } \\
\text { methods } \\
\text { (M) }\end{array}$} & Yield & $\begin{array}{l}\text { Height of } \\
\text { plants }\end{array}$ & $\begin{array}{c}\text { Number of ears } \\
\text { per } 1 \mathrm{~m}^{2}\end{array}$ & $\begin{array}{l}\text { Weight of grains } \\
\text { from ears }\end{array}$ & $\begin{array}{l}\text { Number of } \\
\text { grains from ears }\end{array}$ & $\begin{array}{c}1000 \text { grain } \\
\text { weight }\end{array}$ \\
\hline & & $\mathrm{tha}^{-1}$ & $\mathrm{~cm}$ & no $m^{-2}$ & $\mathrm{~g}$ & no & $\mathrm{g}$ \\
\hline \multirow{6}{*}{$\begin{array}{c}\text { Basic } \\
\text { fertilization } \\
(\mathrm{F} 1)\end{array}$} & A & 4.80 & 90.7 & 350.7 & 1.21 & 31.4 & 38.66 \\
\hline & B & 4.64 & 73.8 & 347.6 & 1.23 & 32.8 & 37.04 \\
\hline & $\mathrm{C}$ & 4.83 & 74.0 & 349.2 & 1.18 & 32.1 & 36.35 \\
\hline & D & 5.00 & 76.5 & 357.9 & 1.25 & 32.1 & 39.86 \\
\hline & E & 5.10 & 75.9 & 340.0 & 1.17 & 32.4 & 38.68 \\
\hline & Mean & 4.87 & 78.2 & 349.1 & 1.21 & 32.2 & 38.12 \\
\hline \multirow{6}{*}{$\begin{array}{l}\text { Intensive } \\
\text { fertilization } \\
\quad(\mathrm{F} 2)\end{array}$} & A & 5.08 & 88.8 & 352.5 & 1.27 & 32.5 & 40.13 \\
\hline & B & 4.93 & 75.1 & 358.8 & 1.23 & 33.2 & 37.26 \\
\hline & C & 5.18 & 73.1 & 375.8 & 1.20 & 31.8 & 37.92 \\
\hline & D & 5.26 & 77.7 & 379.4 & 1.22 & 30.9 & 41.23 \\
\hline & E & 5.42 & 75.7 & 378.1 & 1.20 & 29.8 & 41.38 \\
\hline & Mean & 5.18 & 78.1 & 368.9 & 1.22 & 31.6 & 39.58 \\
\hline \multirow{5}{*}{$\begin{array}{l}\text { Averages } \\
\text { for chemical } \\
\text { protection } \\
\text { methods }\end{array}$} & A & 4.94 & 89.7 & 351.6 & 1.24 & 31.9 & 39.40 \\
\hline & B & 4.79 & 74.4 & 353.2 & 1.23 & 33.0 & 37.15 \\
\hline & C & 5.00 & 73.5 & 362.5 & 1.19 & 31.9 & 37.14 \\
\hline & $\mathrm{D}$ & 5.13 & 77.1 & 368.6 & 1.23 & 31.5 & 40.54 \\
\hline & E & 5.26 & 75.8 & 359.1 & 1.19 & 31.1 & 40.03 \\
\hline \multicolumn{8}{|c|}{$\operatorname{LSD}_{(0.05)}$} \\
\hline \multicolumn{2}{|c|}{$\mathrm{M}$} & 0.30 & 4.1 & NS & NS & NS & 1.31 \\
\hline \multicolumn{2}{|c|}{ F } & 0.13 & NS & 18.9 & NS & NS & 0.59 \\
\hline \multicolumn{2}{|c|}{$M \times F$} & NS & NS & NS & NS & NS & NS \\
\hline
\end{tabular}

Source: Own calculations 
wheat. In the research of Shekoofa and Emam [23], the application of retardants significantly increased TGW of winter wheat, whereas Matysiak [5] demonstrated that these chemicals can cause only a small increase in the trait in question. Miziniak and Praczyk [25-26] did not show the applied mixtures of fenoxapropP-ethyl and sulfosulfuron with retardants to have a significant effect on TGW of winter wheat. In the present experiment, on the other hand, wheat produced the smallest grains in both treatments with the retardant Antywylegacz Płynny 675 SL. Both in the control treatment and in the treatments with the retardant Cerone $480 \mathrm{SL}$, a significant increase in the trait in question was found relative to the control treatment. The highest TGW, which was $40.54 \mathrm{~g}$, was obtained in treatment $\mathrm{D}$, in which ethephon and the herbicide were applied at the growth stages of wheat recommended by the manufacturer (Table 3).

The results of the research of many authors revealed a stimulating effect of nitrogen fertilization on the growth of cereal crops [17, 30], but significant differences relative to the control were usually found after the application of rates higher than $120 \mathrm{~kg} \mathrm{ha}{ }^{-1}$. However, not all experiments confirm this trend; for example, Shekoofa and Emam [23] obtained higher winter wheat plants after the application of $100 \mathrm{~kg} \mathrm{~N} \mathrm{ha}^{-1}$ than in the case of a twice higher rate. The present experiment did not find the mineral fertilizer rates applied to affect spring wheat plant height. In both fertilization treatments, the average plant height was practically identical. On the other hand, the response of spring wheat to the retardants applied was statistically proven. In each experimental treatment with retardant application, a significant decrease in plant height was found in relation to the control treatment. In this experiment, similar to the study of Miziniak and Praczyk [25-26], the combined application of the herbicide with the retardants caused a greater shortening of wheat plants compared to the separate application of these substances, despite the fact that no significant differences were found. The experimental factors did not result in significant differences in grain number and weight per ear.

Table 2. Some quality parameters of spring wheat grain depending on the crop protection method and mineral fertilization level (mean from 2010-2013).

\begin{tabular}{|c|c|c|c|c|c|c|}
\hline \multirow{2}{*}{$\begin{array}{l}\text { Fertilization } \\
\text { (F) }\end{array}$} & \multirow{2}{*}{$\begin{array}{l}\text { Chemical protection } \\
\text { methods }(\mathrm{M})\end{array}$} & Total protein & Gluten & Starch & $\begin{array}{l}\text { Zelene'go sedimentation } \\
\text { index }\end{array}$ & Test weight \\
\hline & & $\mathrm{g} \mathrm{kg}^{-1}$ & $\mathrm{~g} \mathrm{~kg}^{-1}$ & $\mathrm{~g} \mathrm{~kg}^{-1}$ & $\mathrm{ml}$ & $\mathrm{kg} \mathrm{hl}^{-1}$ \\
\hline \multirow{6}{*}{$\begin{array}{l}\text { Basic } \\
\text { fertilization }(F 1)\end{array}$} & A & 12.61 & 23.76 & 51.39 & 34.86 & 77.77 \\
\hline & B & 12.99 & 25.21 & 51.19 & 34.61 & 76.42 \\
\hline & $\mathrm{C}$ & 12.70 & 24.51 & 51.56 & 33.29 & 76.27 \\
\hline & $\mathrm{D}$ & 12.72 & 24.40 & 51.57 & 33.93 & 78.24 \\
\hline & $\mathrm{E}$ & 13.05 & 24.93 & 50.99 & 36.40 & 77.37 \\
\hline & Mean & 12.81 & 24.56 & 51.34 & 34.51 & 77.21 \\
\hline \multirow{6}{*}{$\begin{array}{c}\text { Intensive } \\
\text { fertilization (F2) }\end{array}$} & A & 15.34 & 31.91 & 49.40 & 52.31 & 78.11 \\
\hline & B & 15.41 & 32.00 & 49.08 & 53.72 & 77.16 \\
\hline & $\mathrm{C}$ & 15.02 & 31.07 & 49.40 & 50.26 & 77.28 \\
\hline & $\mathrm{D}$ & 15.24 & 31.68 & 49.64 & 52.42 & 79.37 \\
\hline & $\mathrm{E}$ & 15.35 & 32.03 & 49.53 & 52.54 & 78.69 \\
\hline & Mean & 15.27 & 31.74 & 49.41 & 52.25 & 78.12 \\
\hline \multirow{5}{*}{$\begin{array}{l}\text { Averages for } \\
\text { chemical } \\
\text { protection } \\
\text { methods }\end{array}$} & A & 13.97 & 27.83 & 50.39 & 43.59 & 77.94 \\
\hline & $\mathrm{B}$ & 14.20 & 28.60 & 50.14 & 44.16 & 76.79 \\
\hline & $\mathrm{C}$ & 13.86 & 27.79 & 50.48 & 41.78 & 76.77 \\
\hline & $\mathrm{D}$ & 13.98 & 28.04 & 50.60 & 42.91 & 78.81 \\
\hline & $\mathrm{E}$ & 14.20 & 28.48 & 50.24 & 44.47 & 78.03 \\
\hline \multicolumn{7}{|c|}{$\operatorname{LSD}_{(0.05)}$} \\
\hline & M & NS & NS & NS & NS & 0.85 \\
\hline & $\mathrm{F}$ & 0.30 & 0.91 & 0.30 & 1.84 & 0.38 \\
\hline & $1 \times \mathrm{F}$ & NS & NS & NS & NS & NS \\
\hline
\end{tabular}




\section{Quality Traits of Spring Wheat Grain}

The results of experiments on the influence of retardants on grain quality parameters vary substantially, and study year and fertilization are generally observed to have a greater effect than growth regulators $[5,24]$. The chemical protection methods used in the spring wheat crops did not cause significant differences in the contents of protein, gluten, and starch (Table 2). The highest protein content, which was $14.20 \mathrm{~g} \mathrm{~kg}^{-1}$, was found in treatments $\mathrm{B}$ and $\mathrm{E}$. In treatments $\mathrm{A}, \mathrm{C}$, and $\mathrm{D}$ the contents of this component in spring wheat grain was at a similar level, from $13.86 \mathrm{~g} \mathrm{~kg}^{-1}$ to $13.98 \mathrm{~g} \mathrm{~kg}^{-1}$. Compared to the control treatment (A), a reduction in the gluten content in grain was only found in the case of the combined application of the herbicide and the retardant Antywylegacz Płynny $675 \mathrm{SL}$. In the other chemical protection treatments, this component was found to increase. The highest percentage gluten content was shown in treatment B, i.e., in the case of the separate application of the herbicide and the retardant Antywylegacz Płynny 675 SL. The starch content in wheat grain was at a similar level in all crop protection treatments, ranging from $50.14 \mathrm{~g} \mathrm{~kg}^{-1}$ (treatment B) to $50.60 \mathrm{~g} \mathrm{~kg}^{-1}$ (treatment D).

The huge effect of fertilization on yield chemical composition has already been proved by many researchers [31-32]. In the present experiment, mineral fertilization also modified significantly all the investigated components of spring wheat grain. An increase in NPK fertilizer rate resulted in an average increase in grain protein content by $19.2 \%$, in gluten content by $29.2 \%$, and a decrease in starch content by $3.8 \%$.

The effects of mineral fertilization on the technological quality characteristics of wheat grain are not unambiguous. Some studies showed that high nitrogen fertilizer rates cause grains to be smaller and thus result in a decrease in grain test weight and plumpness, in other studies different nitrogen fertilization levels did not modify grain technological quality, while still others proved their positive effect [33-34]. There are considerably fewer studies on the influence of retardants on wheat technological quality, and those that deal with this issue also do not show a clear effect of these growth regulators on the traits in question. In this experiment, the chemical crop protection methods did not significantly affect the Zeleny sedimentation value (Table 2). Compared to the control (A), the separate application of the herbicide Lintur $70 \mathrm{WG}$ and the retardants in spring wheat, at times recommended by the manufacturers, resulted in an increase in sedimentation value by $1.3 \%$ in the case of the application of Antywylegacz Płynny 675 SL and a $1.6 \%$ decrease after the application of Cerone 480 SL. The combined application of the herbicide and the retardants resulted in a $4.1 \%$ decrease in sedimentation value after the application of Antywylegacz Płynny 675 SL and its increase by $2.1 \%$ after the application of Cerone 480 SL. Mineral fertilization caused significant differences in Zeleny sedimentation value. The higher mineral fertilizer rates significantly increased the sedimentation value.

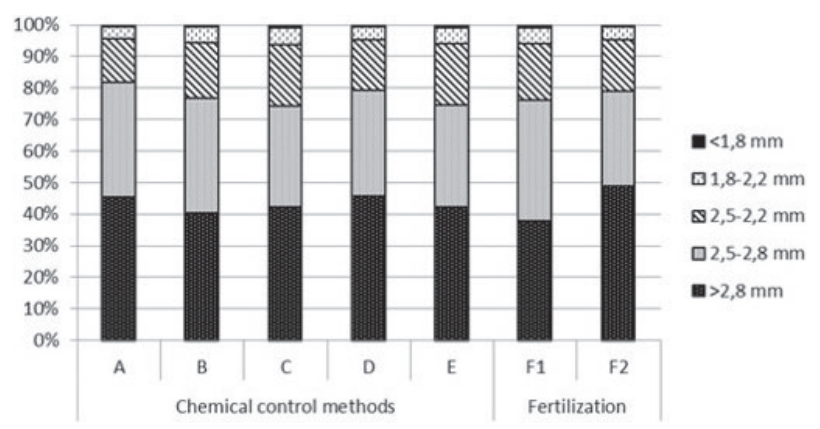

Fig. 1. Grain uniformity of spring wheat.

The chemical crop protection methods caused significant differences in grain test weight (Table 2). The treatments where the retardant Antywylegacz Płynny 675 SL was applied (B, C) were characterized by a significantly lower hectoliter weight compared to the control. In the plots where Cerone 480 SL was applied, the grain test weight was higher than that for the control treatment, but only in the case of the separate application of the herbicide and the retardant (treatment D) was the difference confirmed statistically. NPK fertilizer rates also had a significant effect on the trait in question. Under conditions of higher mineral fertilization, a 1.2\% increase in grain test weight was noted.

Grains from the control treatment (A) exhibited the best uniformity (Fig. 1). Wheat kernels from the treatment where no retardants were used where characterized by the highest percentage of largest grains $(>2.8 \mathrm{~mm})-$ $45.29 \%$, and grains in the $2.5-2.8 \mathrm{~mm}$ fraction $-36.33 \%$. Compared to the basic mineral fertilizer rates, intensive mineral fertilization contributed to an increase in the proportion of the largest grain fraction.

\section{Economic Evaluation}

The next stage of this study was to make an economic evaluation of the effects of the cultivation of spring wheat depending on the crop protection method and mineral fertilization level. We can speak of the optimal effectiveness of specific production processes when they give the best production and economic effects under particular conditions [35]. To this end, based on the yield obtained and the average wholesale price of wheat in the specific year studied, output per hectare of spring wheat crop was determined for the individual production technologies. Due to the fact that straw was not traded, it was not included in the value of output according to the EU methodology.

The data presented in Table 3 show that the output obtained under the particular production technologies varied. The highest average output during 2010-2013 was obtained under intensive fertilization conditions and technology using the combined application of the herbicide Lintur $70 \mathrm{WG}$ and the retardant Cerone $480 \mathrm{SL}$. The least productive technology was the production system based on basic fertilization (B), 
Table 3. Output, costs, and income per hectare of spring wheat grown using different technologies for 2010-2013 (in EUR).

\begin{tabular}{|c|c|c|c|c|c|c|c|}
\hline $\begin{array}{l}\text { Fertilization } \\
\text { levels } \\
\text { (F) }\end{array}$ & $\begin{array}{l}\text { Weed control } \\
\text { methods }(\mathrm{M})\end{array}$ & $\begin{array}{l}\text { Value of } \\
\text { output }\end{array}$ & Direct costs & $\begin{array}{l}\text { Gross } \\
\text { Margin }\end{array}$ & $\begin{array}{l}\text { Net Income } \\
\text { without } \\
\text { subsidies }\end{array}$ & $\begin{array}{l}\text { Net Income with } \\
\text { subsidies and } \\
\text { refund of excise duty }\end{array}$ & $\begin{array}{c}\text { The unit cost } \\
\text { per } t\end{array}$ \\
\hline \multirow{6}{*}{$\begin{array}{l}\text { Basic fertili- } \\
\text { zation (F1) }\end{array}$} & A & 15320.09 & 5319.91 & 9999.77 & 6604.52 & 10601.46 & 1905.27 \\
\hline & B & 14732.02 & 5415.17 & 9316.43 & 5863.86 & 9860.80 & 2037.24 \\
\hline & $\mathrm{C}$ & 15303.60 & 5415.17 & 9888.43 & 6487.81 & 10484.75 & 1934.14 \\
\hline & $\mathrm{D}$ & 16301.59 & 5504.25 & 10797.35 & 7340.23 & 11337.17 & 1798.05 \\
\hline & E & 16220.77 & 5504.25 & 10716.52 & 7311.78 & 11308.72 & 1826.91 \\
\hline & Mean & 15575.61 & 5431.75 & 10143.70 & 6721.64 & 10718.58 & 1900.32 \\
\hline \multirow{6}{*}{$\begin{array}{l}\text { Intensive } \\
\text { fertilization } \\
\text { (F2) }\end{array}$} & A & 16169.22 & 7301.47 & 8867.75 & 5320.73 & 9317.67 & 2222.81 \\
\hline & B & 15644.24 & 7396.73 & 8247.50 & 4643.58 & 8640.52 & 2358.90 \\
\hline & $\mathrm{C}$ & 16510.68 & 7396.73 & 9113.95 & 5561.98 & 9558.92 & 2206.32 \\
\hline & $\mathrm{D}$ & 16760.18 & 7485.81 & 9274.37 & 5665.91 & 9662.85 & 2177.45 \\
\hline & E & 17314.85 & 7485.81 & 9829.45 & 6272.95 & 10269.89 & 2094.97 \\
\hline & Mean & 16479.83 & 7413.31 & 9066.60 & 5493.03 & 9489.97 & 2212.09 \\
\hline \multirow{5}{*}{$\begin{array}{l}\text { Averages } \\
\text { for chemical } \\
\text { protection } \\
\text { methods }\end{array}$} & A & 15744.65 & 6310.69 & 9433.76 & 5962.63 & 9959.57 & 2064.04 \\
\hline & B & 15188.13 & 6405.95 & 8781.97 & 5253.72 & 9250.66 & 2198.07 \\
\hline & $\mathrm{C}$ & 15907.14 & 6405.95 & 9501.19 & 6024.90 & 10021.84 & 2070.23 \\
\hline & $\mathrm{D}$ & 16530.89 & 6495.03 & 10035.86 & 6503.07 & 10500.01 & 1987.75 \\
\hline & E & 16767.81 & 6495.03 & 10272.99 & 6792.37 & 10789.31 & 1960.94 \\
\hline
\end{tabular}

where only the herbicide Lintur $70 \mathrm{WG}$ and the retardant Antywylegacz Płynny 675 SL were used according to the manufacturer's recommendations. The difference between the average output obtained under all technologies using basic fertilization and that obtained under intensive fertilization conditions was €904.2 per ha, on average for the study period, in favor of intensive fertilization.

Nevertheless, the value of output is not the only determinant of the economic margin obtained under individual types of production technology, since this is largely determined by production costs. Therefore, the profitability of production is directly related to its intensity [36]. Among the studied treatments of chemical crop protection of spring wheat crops, the technology used in treatment D with basic fertilization showed the highest profitability as measured by gross margin $(€ 10,797.3)$. This is due to the fact that although the intensive production technologies were accompanied by higher yields, the increase in output was lower than the increase in direct costs. It is worth noting that the absolute difference in output between the technology with the highest level of output (technology E - intensive fertilization) and the technology with its lowest level (technology B - basic fertilization) was $€ 2,582.9$ per ha, whereas the difference in direct costs between the technologies with their highest level (technologies D and E - intensive fertilization) and lowest level (technology A - basic fertilization) was $€ 2,165.9$ per ha over the study period.
The next measure of production profitability is operating income, which was calculated as the difference between gross margin and direct costs. The highest production profitability was achieved for technology D under basic fertilization conditions. In this production system, the average income without direct payments and without excise tax refund for 2010-2013 was €7,340.2 per ha, whereas after including these income components it was $€ 11,337.2$ per ha. A similar level of income was generated in the case of technology E, where the herbicide Lintur $70 \mathrm{WG}$ was applied in combination with the retardant Cerone $480 \mathrm{SL}$ at $\mathrm{BBCH} 30$. Under intensive fertilization conditions, the most profitable technology was treatment E. However, after the incorporation of almost a twice higher amount of NPK fertilizers into the soil, the increase in yield did not compensate for the increase in costs. Due to this, under this technology the level of income with direct payments was lower by $€ 1,038.8$ per ha than the income in the treatment using the same technology under basic fertilization. Skarżyńska [15] also proves in her study that the high intensity of crop production does not ensure a high income in the case of most crops (among others, wheat). Other authors also indicate that relatively high efficiency of production is also achieved when environmentally friendly agricultural practices are used, which at the same time, of course, have a less adverse impact on the environment [37]. 
Table 4. Economic efficiency measures per hectare of spring wheat grown under different technologies for 2010-2013

\begin{tabular}{|c|c|c|c|c|c|c|c|c|}
\hline \multirow{3}{*}{$\begin{array}{l}\text { Fertilization levels } \\
\text { (F) }\end{array}$} & \multirow{3}{*}{$\begin{array}{l}\text { Weed control } \\
\text { methods }(\mathrm{M})\end{array}$} & \multicolumn{7}{|c|}{ Indicators } \\
\hline & & 1 & 2 & 3 & 4 & 5 & 6 & 7 \\
\hline & & $\begin{array}{l}\text { EUR } \\
\text { per t }\end{array}$ & EUR & $\begin{array}{l}\text { EUR } \\
\text { per t }\end{array}$ & EUR & $\begin{array}{l}\text { EUR } \\
\text { per t }\end{array}$ & $\%$ & EUR \\
\hline \multirow{6}{*}{ Basic fertilization (F1) } & A & 1167.91 & 2.87 & 2025.28 & 1.75 & 2163.02 & 26.12 & 1.78 \\
\hline & $\mathrm{B}$ & 1249.56 & 2.71 & 1943.62 & 1.65 & 2075.59 & 30.07 & 2.35 \\
\hline & $\mathrm{C}$ & 1191.82 & 2.82 & 2001.36 & 1.73 & 2138.27 & 27.38 & 1.86 \\
\hline & $\mathrm{D}$ & 1107.28 & 2.95 & 2085.90 & 1.81 & 2198.07 & 22.87 & 1.41 \\
\hline & $\mathrm{E}$ & 1132.44 & 2.93 & 2060.74 & 1.81 & 2187.35 & 24.08 & 1.53 \\
\hline & Mean & 1169.80 & 2.86 & 2023.38 & 1.75 & 2152.46 & 26.10 & 1.79 \\
\hline \multirow{6}{*}{ Intensive fertilization (F2) } & A & 1498.65 & 2.20 & 1694.53 & 1.48 & 1791.86 & 30.10 & 3.05 \\
\hline & $\mathrm{B}$ & 1588.14 & 2.11 & 1605.04 & 1.41 & 1695.36 & 35.52 & 5.12 \\
\hline & $\mathrm{C}$ & 1494.11 & 2.22 & 1699.07 & 1.50 & 1794.33 & 29.47 & 3.04 \\
\hline & D & 1471.02 & 2.23 & 1722.17 & 1.50 & 1802.99 & 27.86 & 2.67 \\
\hline & $\mathrm{E}$ & 1420.70 & 2.30 & 1772.06 & 1.56 & 1859.91 & 25.29 & 2.32 \\
\hline & Mean & 1494.52 & 2.21 & 1698.58 & 1.49 & 1788.89 & 29.65 & 3.24 \\
\hline \multirow{3}{*}{$\begin{array}{l}\text { Averages for chemical protection } \\
\text { methods }\end{array}$} & A & 1333.28 & 2.54 & 1859.91 & 1.62 & 1977.44 & 28.11 & 2.42 \\
\hline & B & 1418.85 & 2.41 & 1774.33 & 1.53 & 1885.47 & 32.80 & 3.74 \\
\hline & C & 1342.97 & 2.52 & 1850.21 & 1.62 & 1966.30 & 28.43 & 2.45 \\
\hline
\end{tabular}

Indicators shown in the table: 1 - Direct costs per $1 \mathrm{t}$ of main product; 2 - Total output per EUR 1 of direct costs; 3 - Gross margin per $1 \mathrm{t}$ of main product; 4 - Ratio of grain selling price to unit cost of production; 5 - Operating income with direct payments per $t$ of grain; 6 - Share of direct payments in operating income; 7 - Ratio of total costs to operating income without direct payments.

The inputs made under the individual production technologies determined the level of unit costs of production of spring wheat. The average unit cost of production of $1 \mathrm{t}$ (ton) of wheat grown under basic fertilization conditions was $€ 1,900.3$ per $t$ over the study period, whereas in the case of intensive technologies it was higher by $€ 311.8$ per $\mathrm{t}$ and averaged $€ 2,212.1$ per $\mathrm{t}$. The lowest costs of production of $1 \mathrm{t}$ of grain were in the technologies that generated the highest level of income per ha, i.e., in the case of basic fertilization it was technology $\mathrm{D}$, while for intensive fertilization it was technology $\mathrm{E}$.

The economic efficiency measures, which show the relationships between the variables studied, complement the calculation of the gross margin and operating income (Table 4). The first of the indicators mentioned in Table 4 shows the amount of direct costs incurred to produce $1 \mathrm{t}$ of spring wheat. The level of this indicator is evidence of the clear advantage of the low-intensity technology. On average per $t$ of grain, under basic fertilization conditions the direct costs were $€ 1,169.8$, whereas in the case of intensive fertilization these costs were $€ 1,494.5$ per $t$. This finding is also confirmed by the efficiency ratio for direct costs, according to which under basic fertilization $€ 1$ of direct costs resulted in the production of output ranging from $€ 2.95$ under treatment $D$ to $€ 2.71$ under technology
$\mathrm{B}$, whereas in the intensive fertilization treatments this value ranged from $€ 2.30$ (E) to $€ 2.11$ (B). The gross margin earned per $t$ of grain was higher in the case of the extensive technologies than under intensive fertilization conditions. The difference between the extreme values of the indicator in question (i.e., between technology D with basic fertilization and technology $\mathrm{B}$ with intensive fertilization) was $€ 480.86$ per $\mathrm{t}$ in favor of the former of the above-mentioned treatments. Nieróbca et al. [36] also indicates a worsening of economic effects as a result of intensification of cereal cropping systems, with a simultaneous increase in yield.

The next indicators also make a case in favor of the cropping treatments under basic fertilization conditions, in particular the technology with the application of the retardant Cerone $480 \mathrm{SL}$. The ratio of grain selling price to unit cost of production was in both cases $€ 1.81$, which was better by $€ 0.32$ than on average under intensive fertilization. The numerical data presented demonstrate that direct payments had a significant impact on the profitability of production. Their average percentage was $26.10 \%$ and $29.65 \%$ under basic and intensive fertilization conditions, respectively. The last of the economic efficiency indicators, the ratio of total costs to operating income without direct payments, confirms 
the above-indicated relationships regarding the higher cost-effectiveness of the technologies using extensive fertilization. The lowest, i.e., most favorable, level of this ratio was found for technology $\mathrm{D}$ (the herbicide Lintur $70 \mathrm{WG}$ applied at $\mathrm{BBCH}=21-22$ and the retardant Cerone $480 \mathrm{SL}$ applied at $\mathrm{BBCH}=31-32$ ) with a low level of fertilization.

\section{Conclusions}

In a market economy, cost-effectiveness is the basic criterion in production management. The use of costbenefit analysis allows us to make rational decisions, which is particularly important in the case of agricultural producers who are price-takers operating under the conditions of an excess of supply over demand. The profitability of and rationale for spring wheat cultivation are determined not only by costs incurred, but also by selling prices, favorable weather conditions, and the high productivity of spring wheat. However, the situation in the agricultural market often forces agricultural producers to seek non-price factors of competition. Producing products of high quality or with some other unique characteristics provides such an opportunity. The evaluation of the obtained results revealed that significantly higher grain yields and with better quality parameters were obtained by using intensive mineral fertilization (F2). However, an analysis of the indicators used to evaluate the economic effects of the spring wheat production technologies investigated showed a clear advantage of the lower intensity technology over the more intensive ones, which should be associated with the high costs of mineral fertilization that were not compensated for by the yields obtained, since the average increase in yield was barely $0.31 \mathrm{t} \mathrm{ha}^{-1}$.

The present experiment proved that the combined application of the herbicide Lintur $70 \mathrm{WG}$ with retardants does not adversely affect spring wheat grain yield and quality, and that the lower unit costs of production indicate the competitive advantage of these technologies. In terms of spring wheat productivity, treatment with the combined application of the herbicide Lintur $70 \mathrm{WG}$ and the retardant Cerone 480 SL under intensive mineral fertilization conditions proved most beneficial. However, taking into account the cost-benefit analysis performed, it would be advisable to use the above-mentioned crop protection method and basic mineral fertilization, because although the spring wheat grain yield was lower by $0.34 \mathrm{t} \mathrm{ha}^{-1}$ in this treatment, the operating income without direct payments was higher by $€ 1038.8$ per ha. The advantage of the less intensive technologies over those with a higher level of fertilization is also due to the less adverse impacts on the environment. Therefore, such a farming system is consistent with the European model of sustainable agriculture which, apart from economic functions, also provides ecological and social functions.

\section{References}

1. ARR Grain Market in Poland. November, Warszawa, 2013 [In Polish].

2. MĄDRY W., PADEREWSKI J., GOZDOWSKI D., ROZBICKI J., GOLBA J., PIECHOCIŃSKI M., STUDNICKI M., DEREJKO A. Adaptation of winter wheat cultivars to crop managements and polish agricultural environments. Turk. J. Agric. For. 18 (1), 121, 2013.

3. SAFA M., SAMARASINGHE S., MOHSEN M. Modeling fuel consumption in wheat production using neural networks. 18th World IMACS - MODSIM Congress, Cairns, Australia 13-17 July, 2009. Available at http:// mssanz.org.au/modsim09 (accessed 10 June 2016).

4. MANDIC V., KRNJAJA V., TOMIC Z., BIJELIC Z., SIMIC A., RUZIC MUSLIC D., GOGIC M. Nitrogen fertilizer influence on wheat yield and use efficiency under different environmental conditions. Chil. J. Agric. Res. 75 (1), 92, 2015

5. MATYSIAK K. Influence of trinexapac-ethyl on growth and development of winter wheat. J. Plant Prot. Res. 46, 134, 2006.

6. ESPINDULA M.C., ROCHA V.S., GROSSI J.A.S., SOUZA M.A., SOUZA L.T., FAVARATO L.F. Use of growth retardants in wheat. Planta Daninha 27, 385, 2009.

7. SILVA T.R.B., SCHMIDT R., SILVA C.A.T., NOLLA A., FAVERO F., POLETINE J.P. Effect of trinexapac-ethyl and nitrogen fertilization on wheat growth and yield. J. Food Agric. Environ. 9, 597, 2011.

8. SAWAN Z.M. Direct and residual effects of plant nutrition's and plant growth retardants, on cottonseed. Agric. Sci. 4 (12A), 84, 2013.

9. KRASOWICZ S. The role of economic evaluation in agricultural research. JARD, 2, 93, 2009.

10. OLEKSY A., SZMIGIEL A., KOŁODZIEJCZYK M. Effect of cultivation intensity on protein concentrations and its yield of the winter wheat cultivars. Acta Sci. Pol., Agric. 7, 47, 2008.

11. CALISKAN S., ERDOGAN C., ARSLAN M., CALISKANE M. Comparison of organic and traditional production systems in chickpea (Cicer arietinum L.). Turk. J. Agric. For. 18 (1), 35, 2013.

12. AUGUSTYŃSKA-GRZYMEK I., CHOLEWA M., MAŃKO S., NACHTMAN G., SKARŻYŃSKA A., Ziętek I. Production, costs and gross margin of selected agricultural products in 2007. No. 100, IERiGŻ, Warszawa, 2008 [In Polish].

13. BIELSKI S. Economic efficiency of winter triticale grain production. Acta Sci. Pol., Oecon., 13, 18, 2014.

14. BUKS J., FLORIAŃCZYK Z., TOCZYŃSKI T. Issues of productivity in the development strategies and its measurement in relation to sustainable farms. IERiGŻ, Warszawa, 2012 [In Polish].

15. SKARŻYŃSKA A. Cropping intensity vs. profitability of selected plant production activities in Poland. Stud. Agric. Econ. 114, 33, 2012.

16. KOSTIC-NIKOLIC S., NIKOLIC I. Significance of Quality through the whole Supply Chain in the Food Industry. Human And Social Sciences at the Common Conference, November 2013. Available at http://www.hassacc.com (accessed 15 June 2016).

17. ELLAMNN T. Effect of plant protection, nitrogen fertilization and time of harvest on the yield of winter wheat. Fragm. Agron. 28, 24, 2011.

18. POLAT H.E., Integration the effects of different storage 
types on nutritional quality characteristics of some feedstuffs. J. Food Agric. Environ. 11, 901, 2013.

19. PARK H., CLAY D.E., HALL R.G., ROHILA J.S., KHAREL T.P., CLAY S.A., LEE S. Winter wheat quality responses to water, environment, and nitrogen fertilization. Commun. Soil Sci. Plant Anal., 45,1898, 2014.

20. BIEL W., JAROSZEWSKA A., STANKOWSKI S., SADKIEWICZ J., BOŚKO P. Effects of genotype and weed control on the nutrient composition of winter spelt (Triticum aestivum ssp. spelta L.) and common wheat (Triticum aestivum ssp. vulgare). Acta Agric. Scand., Sect. B. Soil Sci. 66, 31, 2016

21. HARASIM E., WESOŁOWSKI M., KWIATKOWSKI C., HARASIM P., STANIAK M., FELEDYN-SZEWCZYK B. The contribution of yield components in determining the productivity of winter wheat (Triticum aestivum L.). Acta Agrobot. 69, 1681, 2016.

22. GORAJ L., MAŃKO S. Accounting and economic analysis of the individual farm. Difin, Warszawa, 2009 [In Polish].

23. SHEKOOFA A., EMAM Y. Effects of nitrogen fertilization and plant growth regulators (PGRs) on yield of wheat (Triticum aestivum L.) cv. Shiraz. J. Agr. Sci. Tech. 10, 105, 2008.

24. RAMBURAN S., GREENFIELD P.L. The effects of chlormequat chloride and ethephon on agronomic and quality characteristics of South African irrigated wheat. S. Afr. J. Plant Soil, 24, 108, 2007.

25. MIZINIAK W., PRACZYK T. Effect of mix application of fenoxaprop-p-ethyl with retardants on growth and yield of winter wheat and Apera spica-venti control. Prog. Plant Prot. 47, 211, 2007.

26. MIZINIAK W., PRACZYK T. Effect of sulfosulfuron + retardants mixtures on growth and yield of winter wheat and Apera spica-venti control. Prog. Plant Prot. 48, 637, 2008.

27. ZHU X., GUO W., DING J., LI C., FENG C., PENG Y. Enhancing nitrogen use efficiency by combinations of nitrogen application amount and time in wheat. J. Plant Nutr. 34, 1755, 2011.
28. HALINIARZ M., GAWĘDA D., BUJAK K., FRANT M., KWIATKOWSKI C. Yield of winter wheat depending on the tillage system. Acta Sci. Pol., Agric. 12, 60, 2013.

29. DUAN W., YU Z., ZHANG Y., WANG D., SHI Y., XU Z. Effects of nitrogen application on biomass accumulation, remobilization, and soil water contents in a rainfed wheat field. Turk. J. Field Crops, 19(1), 26, 2014.

30. FAGERIA N., BALIGAR V., LI Y. The role of nutrient efficient plants in improving crop yields in the twenty first century. J. Plant Nutr. 31,1131, 2008.

31. WRIGHT G.M. Effect of nitrogenous fertiliser on wheat yield and baking quality. New Zeal. J. Agr. Res. 12, 729. 2012.

32. MOHAMMED Y.A., KELLY J., CHIM B.K., RUTTO E., WALDSCHMIDT K., MULLOCK J., TORRES G., DESTA K.G., RAUN W. Nitrogen fertilizer management for improved grain quality and yield in winter wheat in Oklahoma. J. Plant Nutr. 36, 751, 2013.

33. BOUACHA O.D., NOUAIGUIB S., REZGUIA S. Effects of $\mathrm{N}$ and $\mathrm{K}$ fertilizers on durum wheat quality in different environments. J. Cereal Sci. 59, 13, 2014.

34. ROZBICKI J., CEGLIŃSKA A., GOZDOWSKI D., JAKUBCZAK M., CACAK-PIETRZAK G., MĄDRY W., GOLBA J., PIECHOCIŃSKI M., SOBCZYŃSKI G., STUDNICKI M. Influence of the cultivar, environment and management on the grain yield and bread-making quality in winter wheat. J. Cereal Sci. 61, 127, 2015.

35. KOŁOSZKO-CHOMENTOWSKA Z. Economic and technological efficiency of plant production. Pam. Puł. 142, 180, 2006 [In Polish].

36. NIERÓBCA P., GRABIŃSKI J., SZELEŹNIAK E. Influence of production technology intensity of grain species planted in cereal crop rotation on productive and economic effectiveness. Acta Sci. Pol., Agric. 7, 75, 2008.

37. TUOMISTO H.L., HODGE I.D., RIORDAN P., MACDONALD D.W. Assessing the environmental impacts of contrasting farming systems. Asp. Appl. Biol. 93, 168, 2009. 